\title{
Apoptosis- and necrosis-induced changes in light attenuation measured by optical coherence tomography
}

\author{
Freek J. van der Meer • Dirk J. Faber • \\ Maurice C. G. Aalders • Andre A. Poot • \\ Istvan Vermes • Ton G. van Leeuwen
}

Received: 29 December 2008 / Accepted: 31 July 2009 /Published online: 10 September 2009

(C) The Author(s) 2009. This article is published with open access at Springerlink.com

\begin{abstract}
Optical coherence tomography (OCT) was used to determine optical properties of pelleted human fibroblasts in which necrosis or apoptosis had been induced. We analysed the OCT data, including both the scattering properties of the medium and the axial point spread function of the OCT system. The optical attenuation coefficient in necrotic cells decreased from $2.2 \pm 0.3 \mathrm{~mm}^{-1}$ to $1.3 \pm 0.6 \mathrm{~mm}^{-1}$, whereas, in the apoptotic cells, an increase to $6.4 \pm 1.7 \mathrm{~mm}^{-1}$ was observed. The results from cultured cells, as presented in this study, indicate the ability of OCT to detect and differentiate between viable, apoptotic, and necrotic cells, based on their attenuation coefficient. This functional supplement to high-resolution OCT imaging can be of great clinical benefit, enabling on-line monitoring of tissues, e.g. for feedback in cancer treatment.
\end{abstract}

Freek J. van der Meer and Dirk J. Faber contributed equally to the manuscript and the study

F. J. van der Meer · D. J. Faber · M. C. G. Aalders ·

T. G. van Leeuwen

Department of Biomedical Engineering and Physics,

Academic Medical Center, University of Amsterdam,

Amsterdam, The Netherlands

D. J. Faber

Ophthalmology Department, Academic Medical Center,

University of Amsterdam,

Amsterdam, The Netherlands

\section{A. A. Poot $\cdot$ I. Vermes}

Polymer Chemistry and Biomaterials Group,

University of Twente, Institute of Biomedical Technology,

Enschede, The Netherlands

T. G. van Leeuwen $(\square)$

Biophysical Engineering Group, University of Twente,

Institute of Biomedical Technology,

P.O. Box 217, 7500 AE Enschede, The Netherlands

e-mail: t.g.vanleeuwen@amc.uva.nl
Keywords Optical coherence tomography .

Optical properties $\cdot$ Cells $\cdot$ Apoptosis $\cdot$ Necrosis

\section{Introduction}

In every multi-cellular organism a delicate balance exists between cell division, on one hand, and cell death, on the other hand. Cell death can be executed by two different pathways, necrosis and apoptosis [1]. Necrosis, the pathological pathway, is also known as accidental cell death, which is triggered by external disturbances, e.g. physical trauma, chemical stress or hypoxia. Its morphology is characterized by slight initial cellular swelling, followed by cell lysis. In vivo, the resulting cell debris triggers an inflammatory response.

The physiological pathway of cell death is called apoptosis, also known as programmed cell death. It is a general mechanism for the clearance of cells that have become superfluous or show an aberrant function, without causing inflammation. The apoptotic pathway is conducted by a series of tightly regulated biochemical processes in which a cell, once triggered, goes through consecutive phases of cell shrinkage, chromatin condensation and breakdown, nuclear disintegration, cell blebbing and the formation of so-called apoptotic bodies. These apoptotic bodies contain nuclear fragments and cell organelles (Fig. 1). Under normal physiological conditions they are cleared by either macrophages or neighbouring cells through phagocytosis [2].

As the physiological counterpart of cell growth, apoptosis plays an important role in the balance of tissue dynamics. Disturbances in this balance results in disease. If aberrant cells do not undergo apoptosis, a tumour can develop. On the other hand, excessive apoptosis can result in degenerative 


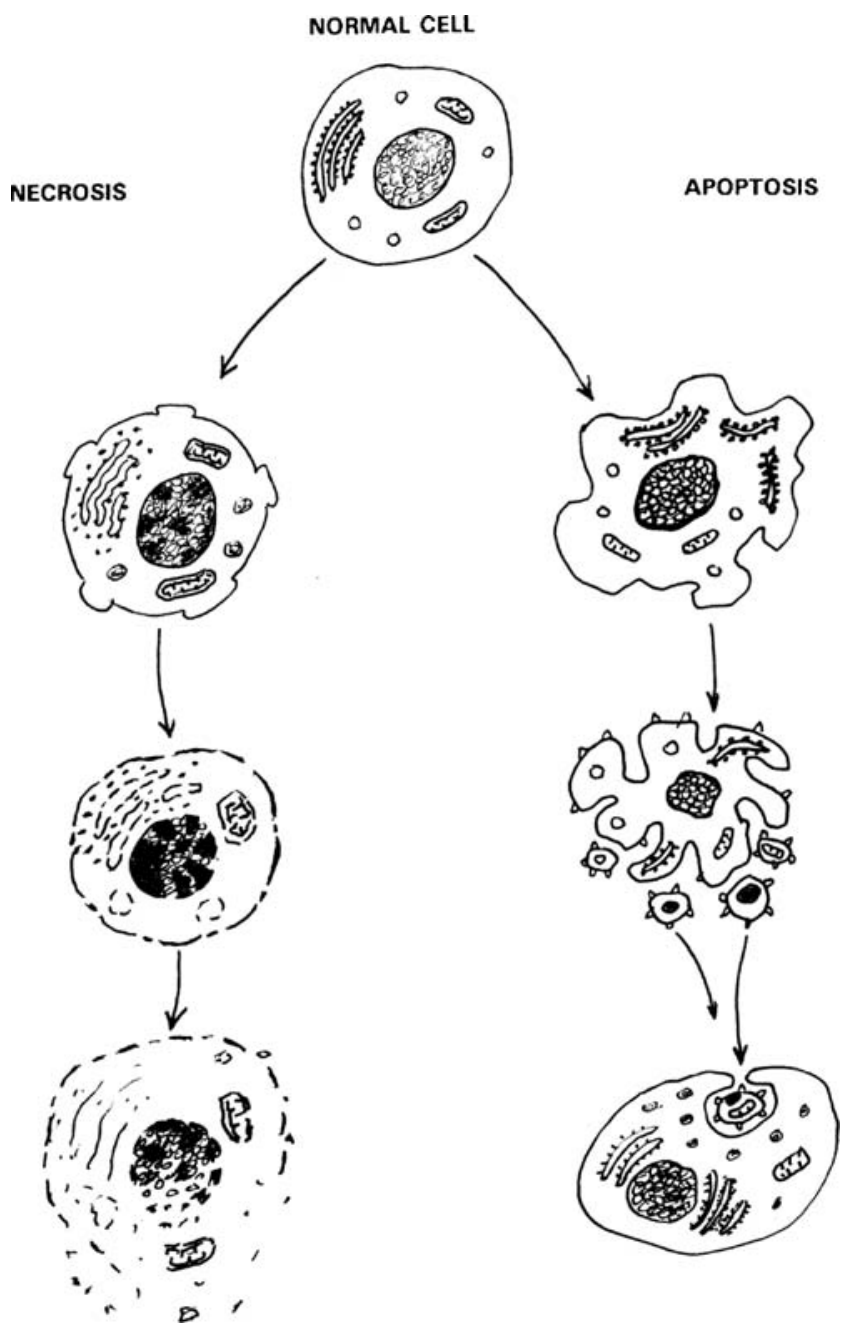

Fig. 1 Schematic representation of the different stages of necrosis (left) and apoptosis (right). The process of necrosis starts with membrane defects, followed by karyolysis and enzyme release, due to cell disintegration. Once apoptosis has been triggered in a normal cell (top), the membrane will change, leading to surface protrusions. The condensed nucleus fragments, which is followed by disintegration of the whole cell into apoptotic bodies, containing remnants of the nucleus and other cell components. Apoptotic bodies are cleared by phagocytosis by macrophages or neighbouring cells, or they undergo secondary necrosis

syndromes, such as atrophy and cardiomyopathy [3]. In clinical practice, treatment of these symptoms and diseases involves reduction or stimulation of apoptosis, respectively. Consequently, there is a strong need for methods that can detect and quantify apoptosis on a microscopic level. Currently, the standard methods of apoptosis detection in tissue are histological or biochemical, which are time consuming and require biopsies [4]. In vivo detection using radionuclide imaging [5] and magnetic resonance imaging [6] is currently under investigation.

Recently, Czarnota and co-workers reported that apoptosis could be detected by high-frequency ultrasound [7]. They observed an increase in backscattering of the ultrasound signal, which they attributed to the disintegration of the nucleus, a distinctive feature of apoptosis. Optical coherence tomography (OCT) imaging, the optical and high-resolution equivalent of ultrasound imaging, is based on time of flightdependent intensity differences of backscattered light [8]. In a previous study we used OCT to image porcine carotid arteries in ex vivo tissue culture [9]. We reported an increase in backscattering in the medial layer after balloon dilation. Since there is a rapid onset of apoptosis after balloon angioplasty [10], we hypothesized that the changes in OCT signal could be attributed to this characteristic form of cell death. Functional OCT allows the quantitative measurement of tissue absorption and scattering properties, at the microscopic level. Because both apoptosis and necrosis directly influence the cell's main scatterers (i.e. nucleus, membrane, mitochondria, and other cellular organelles [1116]), we hypothesized that the local optical attenuation coefficient $\left(\mu_{t}\right)$, which describes the decay of measured intensity against. depth, could be used to assess cell death. Moreover, due to the differences in the morphology of the two pathways of cell death, we hypothesized that differences could be observed in the attenuation of light by necrotic and apoptotic cells compared with that by normal cells and that those changes could be monitored in time, after induction of cell death. In this paper, we describe OCT measurements of the optical attenuation coefficient of pelleted human fibroblasts, in which necrosis or apoptosis had been induced.

\section{Materials and methods}

\section{Cells and reagents}

Human fibroblasts were maintained in Dulbecco's modified Eagle's medium (DMEM) (Gibco/BRL) supplemented with $10 \%$ fetal calf serum, streptomycin at $100 \mu \mathrm{g} / \mathrm{ml}$ and penicillin at $100 \mathrm{U} / \mathrm{ml}$ in a fully humidified atmosphere containing $5 \%$ carbon dioxide $\left(\mathrm{CO}_{2}\right)$ at $37^{\circ} \mathrm{C}$. Prior to the experiment, subconfluent grown cells were trypsinized and collected by centrifugation at $500 \mathrm{~g}$ for $10 \mathrm{~min}$. At time $(\mathrm{t})=0$, the pelleted cells were resuspended in DMEM containing $10 \%$ ethanol, to induce necrosis, or $200 \mu \mathrm{M}$ cytosine arabinoside (AraC, Sigma), to induce apoptosis, or $0.1 \mathrm{mg} / \mathrm{ml}$ colchicine (CX, Sigma), to induce mitotic arrest. After 30 min incubation, the cells were pelleted and imaged by OCT for $6 \mathrm{~h}$. In a second set of experiments the dose-dependency of apoptosis induction by $\mathrm{AraC}$ was studied. Culture flasks with subconfluent grown cells were incubated with $50 \mu \mathrm{M}, 100 \mu \mathrm{M}$ or $200 \mu \mathrm{M}$ AraC for $2 \mathrm{~h}$. The cells were trypsinized and collected by centrifugation at $500 \mathrm{~g}$ for $10 \mathrm{~min}$. Pelleted cells were immersed in medium and imaged by OCT at $3 \mathrm{~h}, 6 \mathrm{~h}, 9 \mathrm{~h}$, $12 \mathrm{~h}$ and $24 \mathrm{~h}$ after the induction of apoptosis. Between and during measurements the cells were kept at $37^{\circ} \mathrm{C}$. 


\section{Verification of apoptosis}

At the end of the OCT experiment, samples of pelleted cells were subjected to immunofluorescence analysis, using a commercially available apoptosis detection kit (Sigma). The double-labelling assay with annexin V-Cy3 (AnnV) and 6-carboxyfluorescein diacetate (CFDA) allows differentiation between apoptotic, necrotic and viable cells. The CFDA is processed in metabolically active cells into fluorescing 6-carboxyfluorescein (6-CF). The AnnV-Cy3 label binds to phosphatidyl serine residues when they appear in the outer leaflet of the cell membrane, which occurs in compromised cells that are apoptotic or necrotic. Therefore, cells that are labelled only with 6-CF (green) are viable cells, cells labelled only with Ann-Cy3 (red) are necrotic cells, and cells stained with both are apoptotic. The cells were labelled in accordance with the manufacturer's instructions.

\section{Flow cytometry}

To measure the necrotic and apoptotic fraction after induction of cell death, we harvested cells at different time points and washed them in ice-cold 4-(2-hydroxyethyl)-1-piperazineethane-sulphonic acid (HEPES) buffer $[10 \mathrm{mM}$ HEPES, $150 \mathrm{mM}$ potassium chloride $(\mathrm{KCl}), 1 \mathrm{mM}$ magnesium chloride $\left(\mathrm{MgCl}_{2}\right)$ and $1.3 \mathrm{mM}$ calcium chloride $\left(\mathrm{CaCl}_{2}\right)$, $\mathrm{pH}$ 7.4] supplemented with $1 \mathrm{mg} / \mathrm{ml}$ glucose and $0.5 \%(\mathrm{w} / \mathrm{v})$ bovine serum albumin (BSA). The cells were then incubated with fluorescein isothiocyanate (FITC)-labelled annexin V (diluted 1:200 in HEPES buffer) for 15 min and washed again in HEPES buffer. Just before analysis of the samples by flow cytometry (FACSCalibur, Becton Dickinson, San Jose, CA, USA), propidium iodide (PI) was added (final concentration $5 \mu \mathrm{g} / \mathrm{ml}$ ) to distinguish necrotic cells (annexin $\mathrm{V}-/ \mathrm{PI}+$ ) from early apoptotic cells (annexin $\mathrm{V}+/$ $\mathrm{PI}-$ ) and late apoptotic cells (annexin $\mathrm{V}+/ \mathrm{PI}+$ ) [4]. The samples were analysed with a FACSCalibur (Becton Dickinson) instrument equipped with CellQuest software. The cytometer was calibrated by eye with the fluorochrome beads supplied by the manufacturer.

\section{OCT imaging}

The cells were imaged with a high-resolution timedomain OCT setup in which a titanium (Ti):sapphire laser (FemtoSource, Vienna, Austria), operating at a central wavelength of $800 \mathrm{~nm}$ with a bandwidth of $125 \mathrm{~nm}$, was used as the light source. Depth scanning, by changing the length of the (optical) path in the reference arm, was performed using a so-called rapid-scanning optical delay (RSOD) line [17] in which a linear galvanometer was used. This allowed precise and constant (speed and intensity) depth ranging at the expense of reduced imaging speed. Moreover, it allowed hardware-based compensation for the dispersion mismatch between the reference arm and sample arm. In-depth scanning was performed at 25 lines per second. For this system, we measured a dynamic range of $110 \mathrm{~dB}$ and a free space axial resolution of $5 \mu \mathrm{m}$. For each cell pellet and each time point three to five $b$-scans were made.

\section{Data analysis}

In each b-scan, the attenuation coefficient $\left(\mu_{t}\right)$ of the pelleted cells was obtained in a procedure described previously [18]. In short, the depth dependence of the amplitude of the OCT signal can be described as the product of the axial point spread function (PSF) of the optics used and the attenuation of the light by the tissue structures [19-21]. An average signal of 50-100 adjacent A-scans as a function of depth was fitted to the model with $\mu_{\mathrm{t}}$ as a fitting parameter, incorporating both the known location of the focus in the tissue and the previously measured depth of focus of the imaging optics.

\section{Results}

In the experiments described in this study the cells were pelleted and were proven to be viable (data not shown), as in other studies [22-24]. Qualitatively, when compared with untreated cells (Fig. 2a), the cells treated with $200 \mu \mathrm{M} \mathrm{AraC}$ exhibited a temporary increase in OCT signal and a decrease in imaging depth (Fig. 2b). In contrast, cells treated with $10 \%$ ethanol showed an increase in imaging depth (Fig. 2c). These observations are quantified by the measurement of $\mu_{t}$ of the samples in time as presented in Fig. 3. The AraCtreated cells show an initial increase in $\mu_{\mathrm{t}}$, followed by a decrease, ending up below the level of the control cells. Treatment with $10 \%$ ethanol $(\mathrm{EtOH})$ results in an immediate decrease in backscatter, compared to untreated control cells.

As shown in the fluorescence images (Fig. 4), apoptosis was induced in the AraC-treated cells. Panels $4 \mathrm{a}$ and $4 \mathrm{~b}$ show untreated control cells, and panels $4 \mathrm{c}$ and $4 \mathrm{~d}$ show AraCtreated cells. The green fluorescence (Fig. 4a, c) is a marker for metabolically active cells (i.e. either viable or apoptotic cells), whereas the red fluorescence marks the compromised cells (i.e. necrotic or apoptotic cells). Therefore, the doublelabelled cells can be discerned between viable (green), apoptotic (green and red), and necrotic (red) cells.

Since the necrotic process rapidly results in the clearance of cells by rupture of the cell membranes, the EtOH- treated cells were not visualized by fluorescence microscopy. Fluorescence-activated cell sorter (FACS) analysis can detect necrotic cells based on the scattering of remnants. The result of the cell counting is presented in Fig. 5. The decrease in average attenuation (dotted line) coincides with 
Fig. 2 Examples of

OCT images of pelleted cells. Untreated control cells (a) remained unchanged during the entire experiment. Apoptotic AraC-treated cells (b) showed an increase in scattering in the top layer, whereas necrosis (c) resulted in a decrease in signal

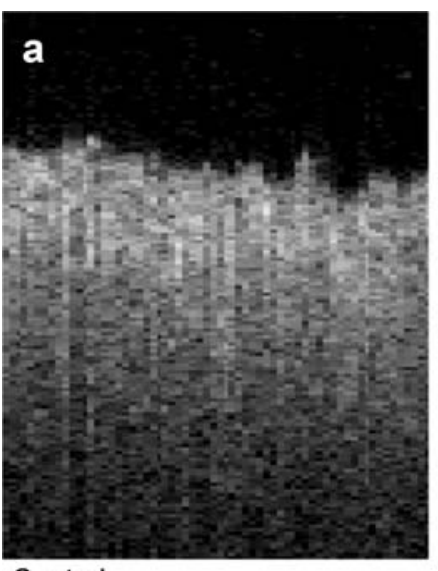

Control

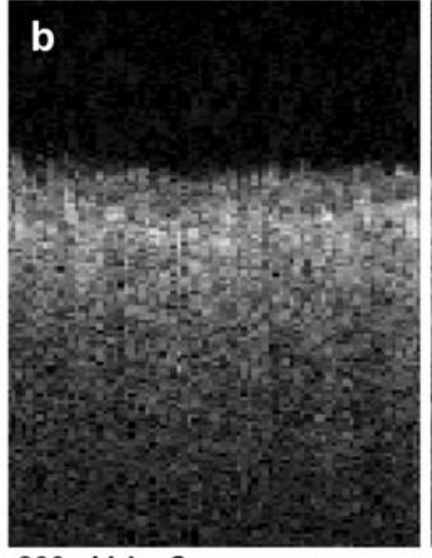

$200 \mu \mathrm{M}$ AraC

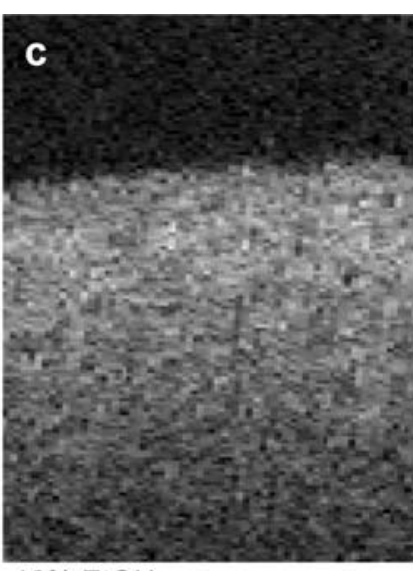

$10 \% \mathrm{EtOH}$ a decrease in viable cells (grey line) and a synchronous increase in necrotic cells. No apoptotic cells were detected; therefore, the decreasing total cell count has to be attributed to the total clearance of necrotic cells.

The induction of apoptosis by $\mathrm{AraC}$ is known to be dependent on the concentration. In Fig. 6 the results are plotted of the attenuation measurement of cells treated with $50 \mu \mathrm{M}$ (Fig. 6a), $100 \mu \mathrm{M}$ (Fig. 6b), and $200 \mu \mathrm{M}$ (Fig. 6c). The higher the concentration of $\mathrm{AraC}$, the earlier the rise in attenuation is observed.

To study the effect of nuclear condensation on the attenuation, we treated cells with colchicine (Fig. 7). The resulting increase in $\mu_{\mathrm{t}}$ mimicked the apoptosis curves.

\section{Discussion}

In the experiments described in this paper, an increase in $\mu_{\mathrm{t}}$ was observed in pelleted cells after treatment with AraC. $\mathrm{AraC}$ is known to induce apoptosis via incorporation into DNA during replication, acting as a chain terminator [25].

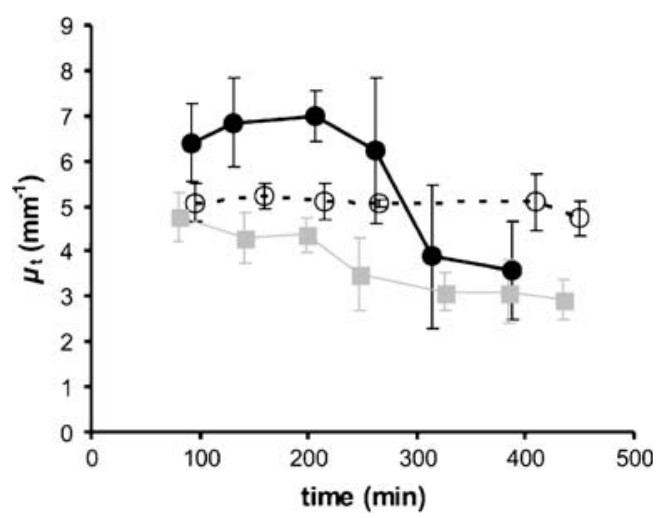

Fig. 3 The attenuation coefficient measured in pelleted human fibroblasts, as a function of time. Time was measured in minutes from the point that the cells were forced into necrosis (filled squares) or apoptosis (filled dots). Sham-treated (control) cells show no change in scattering (circles)
However, AraC can also induce apoptosis directly through oxidative stress, with an increase in the generation of reactive oxygen species and tumour suppressor protein 53 (p53)-dependent cytotoxicity [26, 27]. This latter, rapid, pathway has been shown to induce apoptosis in lymphoid cells within 3 hours [26]. Apart from its use in leukemia treatment, its use is known to induce apoptosis in neuronal cells [28] and fibroblasts [29].

Apoptosis was, indeed, detected with a commercially available viability assay, combining 6-CDFA with an annexin V-Cy3 label. Annexin V binds to the phosphatidyl serine that is redistributed from the inner to the outer leaflet of the plasma membrane as an early event in the apoptotic programme [30]. Binding of annexin $\mathrm{V}$ to externalized phosphatidyl serine has formed the basis for widely used optical methods (fluorescence microscopy and flow cytometry) for detecting apoptosis [4]. Furthermore, AraC is known to induce apoptosis in a dose-dependent fashion [31, 32]. A similar dependency was observed in the changes in $\mu_{\mathrm{t}}$ in our experiments.

There is a great variety in apoptosis inducers [33]. In an experimental setup similar to the one described here, we induced apoptosis in mouse fibroblasts (MFs) with staurosporine [33], and subjected human lung carcinoma cell line (SW 1573) to 5-aminolaevulinic acid-photodynamic therapy (ALA-PDT) [34]. The preliminary results indicated that, in both cell lines, an increase in $\mu_{\mathrm{t}}$ was observed (data not shown).

The origin of light scattering from cells is still the subject of studies. Scattering occurs due to the mismatch in indices of refraction between these different cellular compartments and is also dependent on the size and shape of the scatterer [11, 13, 35-37]. In the case of necrosis, the cell and its organelles disintegrate, resulting in an amorphous mass. The decrease in scattering from necrotic cells can, therefore, probably be explained by the removal of potential scatterers. On the other hand, cellular swelling prior to cell lysis might lead to an initial increase in 
Fig. 4 Images of immunofluorescence labelling of control cells $(\mathbf{a}, \mathbf{b})$ and cells treated with $200 \mathrm{mM} \mathrm{AraC} \mathrm{(c,} \mathrm{d)} \mathrm{at} 24 \mathrm{~h}$. When the green fluorescing label CFDA $(\mathbf{a}, \mathbf{c})$ is used, viable cells can be identified, whereas the red fluorescing label AnnV (b, d) is specific for apoptotic cells. At $24 \mathrm{~h}, 5 \%$ of the control cells have become apoptotic, while, after treatment with $200 \mathrm{mM} \mathrm{AraC}, 61 \%$ of cells are apoptotic
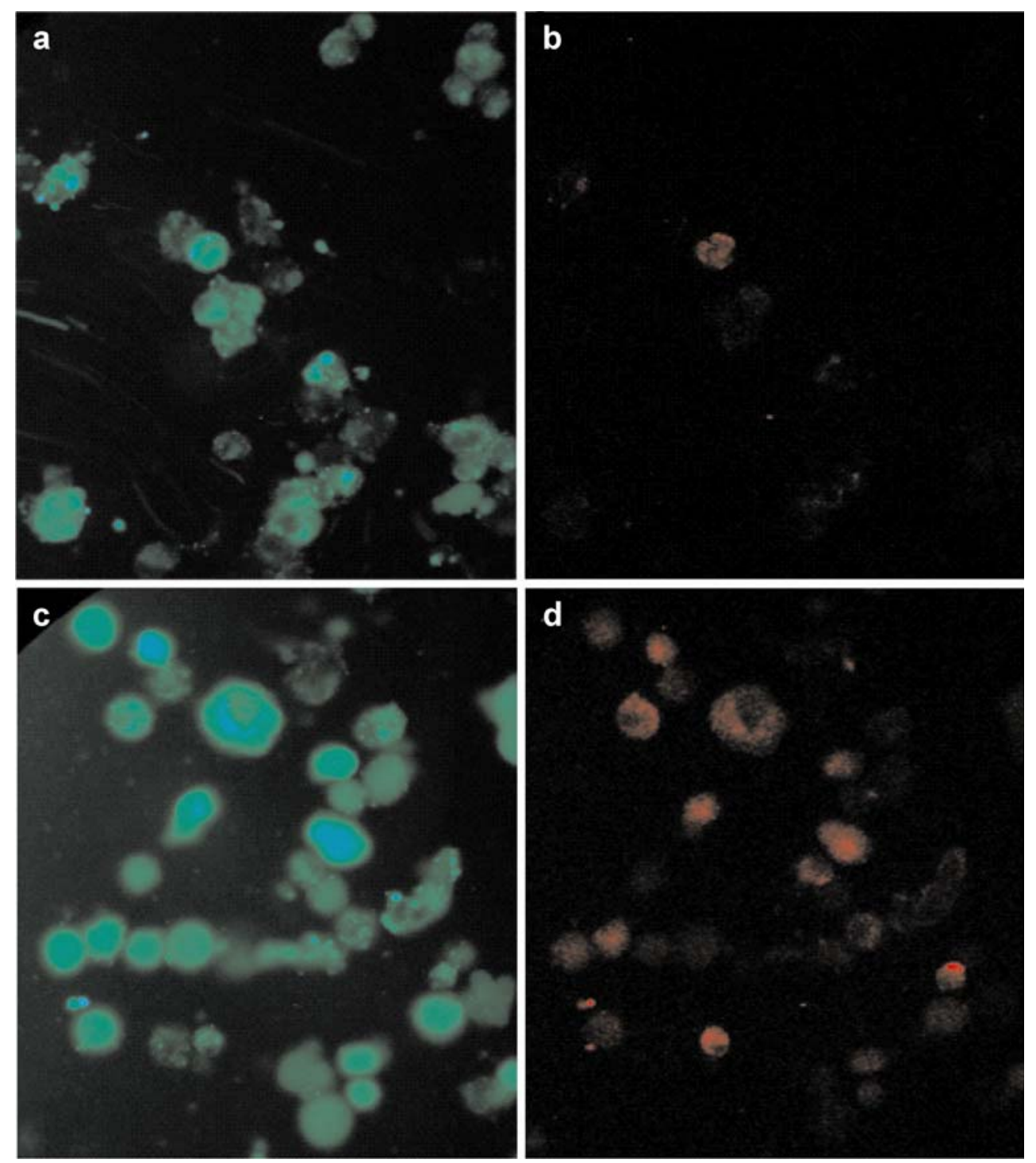

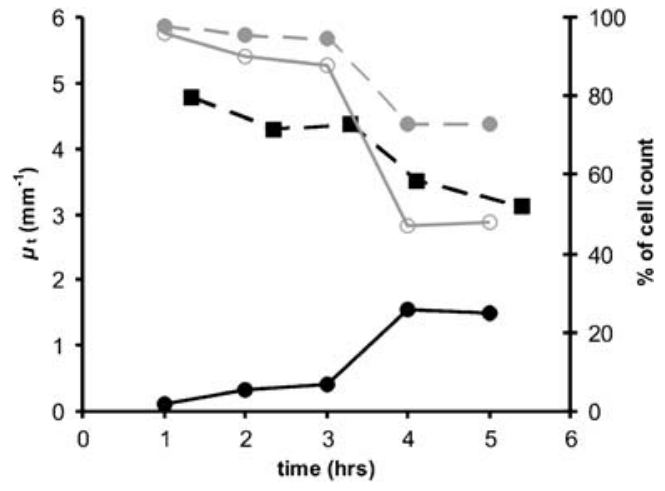

Fig. 5 After induction with $10 \%$ ethanol $(\mathrm{t}=0)$, the number of viable cells (grey line, open dots) decreases and the number of necrotic cells (black line, filled dots) increases. The total number of cells (grey dotted line) decreases, due to loss of necrotic cells. The decrease in $\mu_{\mathrm{t}}$ (black dotted line) coincides with the increase in necrosis scattering, which was not observed in our experiments. Valenzeno and Trank proposed a technique for measurement of the blood haematocrit based on the decrease of forward scattering during erythrocyte lysis. The loss of refractive index mismatches reduced the scattering coefficient and anisotropy [38]. The degree of haemolysis is inversely related to the intensity of small angle scattering. Furthermore, in experiments monitoring the optical density (OD) of cell suspensions, Kravtsov and Fabian reported a clear decrease in OD after the induction of necrosis [12].

The apoptotic process involves a series of morphological changes in which many potential scatterers are involved. It has been reported that the initial increase in scattering could be due to cellular shrinkage [14], to chromatin condensation [16], to nuclear fragmentation [13] or to mitochondrial swelling [39] and release of cytochrome c [40]. In investigations of mitochondrial morphology in apoptosis, single-angle light-scattering data [41] and absorption 


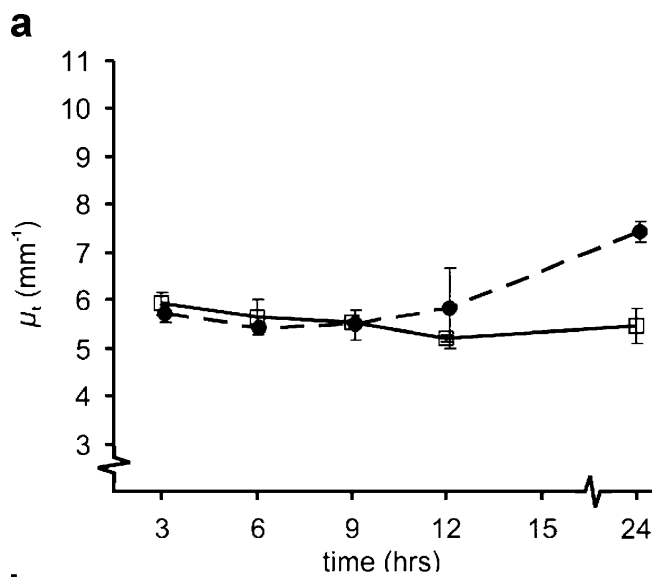

b

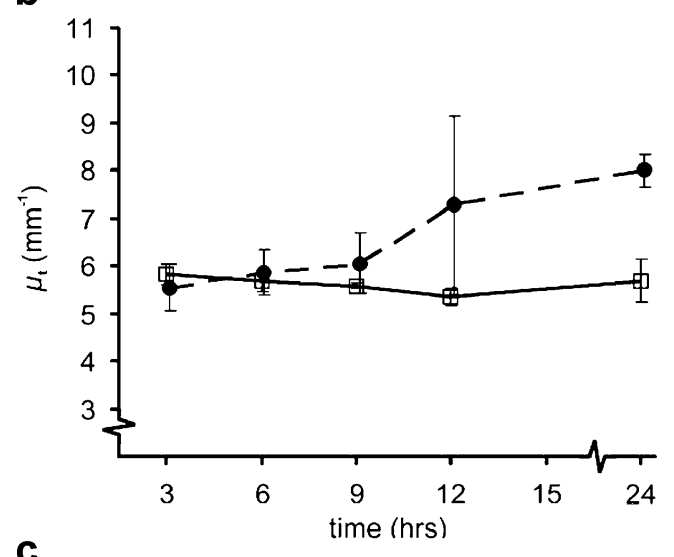

C

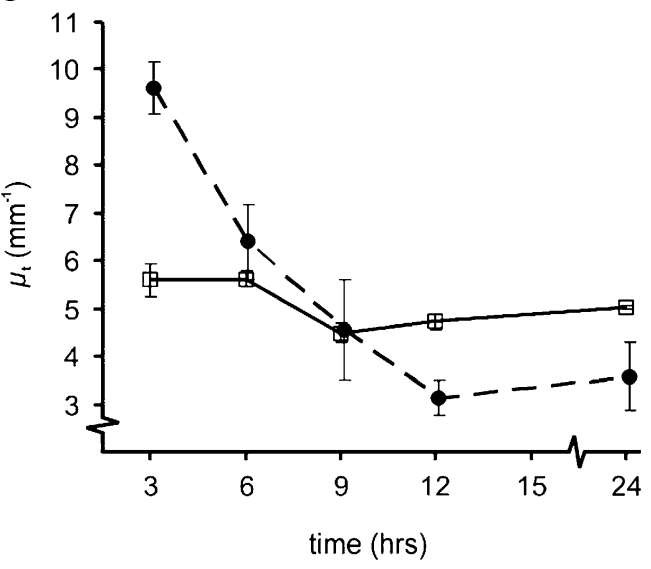

Fig. 6 Dose-dependency curves of the increase in $\mu_{\mathrm{t}}$ after treatment with $50 \mu \mathrm{M}(\mathbf{a}), 100 \mu \mathrm{M}$ (b), and $200 \mu \mathrm{M}$ (c) AraC. The higher the dose, the earlier is the onset of the $\mu_{\mathrm{t}}$ increase. The black lines depict the untreated control cells, and the dotted lines are AraC-treated apoptotic cells

spectrophotometry [42] have been used to detect volume changes in suspensions of viable mitochondria isolated from apoptotic cells. Different results were obtained with these techniques (see, e.g., Kroemer et al. [43]), with some studies showing light scattering suggestive of mitochondrial swelling [41], whereas others showed no change [42]. By measuring the intensity ratio of wide-to-narrow angle

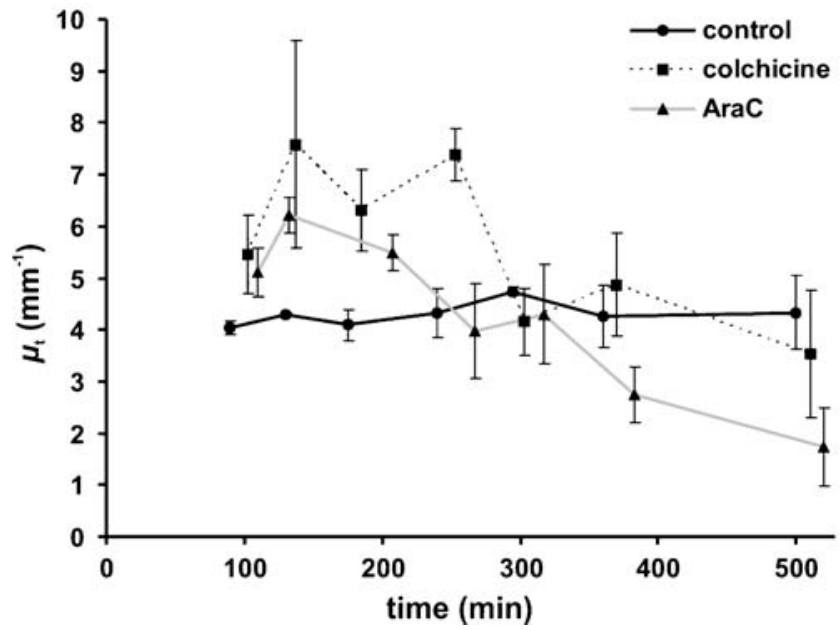

Fig. 7 Colchicine-treated cells (black dotted line) mimic the $\mu_{\mathrm{t}}$ curve of the AraC-treated cells (grey line). However, the maximum values of $\mu_{\mathrm{t}}$ are higher, and secondary necrosis is not significantly detected. Untreated control cells are represented by the black line

scatter in single cells during apoptosis researchers have shown that the changes in the mitochondrial membrane preceded the exposure to phosphatidyl serine [44].

Kravtsov and co-workers [12] designed an assay in which they monitored the OD of cells in suspension. When inducing apoptosis, they observed a temporary increase in OD, comparable to the increase in $\mu_{t}$ in this study. Morphological analysis of their samples revealed that the increase in OD coincided with the blebbing of the apoptotic cell membrane. The initial OD increase was followed by a decrease when the majority of the cells had passed the blebbing stage. If we consider the similarities with the results presented here, especially the transient tendency of the $\mu_{\mathrm{t}}$ increase, it is likely that membrane blebbing is responsible for the results of our study.

In flow cytometry apoptotic cells are also identified on the basis of changes in scattering. Whereas this study focused on backscattered light, cytometry registers forward and side $\left(90^{\circ}\right.$ angle) scattering of single cells. In flow cytometry data analysis, the forward scatter signal is correlated with the cell size, and the side scatter signal is correlated with the cell's refractive and reflective properties and reveals optical inhomogeneity, such as that resulting from condensation of cytoplasm or nucleus and granularity. During the apoptotic process, there is a slight initial decrease in forward scatter (cell shrinkage and mitochondrial swelling), followed by an increase in side scatter (nuclear condensation and fragmentation). The formation of apoptotic bodies is characterized by a decrease in both forward and side scatter [45]. Accordingly, changes in light scatter properties can contribute to the rapid and easy identification of apoptotic cells in particular conditions. 
Czarnota et al. used colchicine to image mitotic arrested cells, which would be normal cells with a condensed nucleus. Whereas the initial goal was to image cells with mere condensed nuclei, possibly also apoptosis was induced in the colchicine-treated cells. Unfortunately, under certain experimental conditions, colchicine is also described as an apoptosis inducer $[46,47]$.

\section{Clinical implications and study limitations}

The monitoring of apoptosis could play an important role in the clinic [1]. Apart from an apparent diagnostic value, online monitoring of apoptosis in response to treatment could greatly improve therapeutic efficacy in, e.g., skin cancer treatment.

Apoptosis also plays a role in cardiovascular disease. Apoptosis of vascular smooth muscle cells [48, 49] and macrophages [50] localizes in so-called vulnerable lesions, i.e. those lesions most likely to rupture, and at sites of actual ruptured plaques. In in vivo studies, induction of apoptosis in endothelial cells as well as in smooth muscle cells has been shown to result in thrombosis [51] and plaque rupture [52], respectively. However, before OCT can be used to detect vascular apoptosis, the specificity and sensitivity of the detection of cell death has to be investigated.

Although the loss of cell integrity during necrosis could be determined by flow cytometry, the identification of apoptosis in fibroblasts met with insurmountable difficulties. Flow cytometry was developed for the analysis of single cells that grow in suspension. Adherent cells, like the fibroblasts used in this study, are very difficult to analyse by cytometry due to clumping of the cells, and rupturing of cells when resuspending. Furthermore, it should be stressed that, because the cells become detached during late stages of apoptosis, many apoptotic cells may be selectively lost if the analysis is limited to the attached cells only [53].

Further research has to be done to elucidate the origin of light scattering by cells in order to address the question of the reason of rapid light scattering changes in dying cells, especially compared to the later observed apoptosis by biochemical methods. Chalut et al. showed that within 1.5 hours of apoptosis induction, the sub-cellular organization, described as the fractal dimension, rapidly decreases [54]. They also observed a biphasic response in time, which was possibly related to mitochondrial swelling, fission and fusion. Similarly, Mulvey et al. recently described rapid changes in scattering of suspensions of cells after induction of apoptosis [55]. Because the index of refraction of membranes is relatively high $(\sim 1.46)$ [56], changes in the membrane structure may have a relatively large effect on the scattering properties. Furthermore, the effect of dependent scattering, e.g. due to the packing of scatterers, may also influence the measurement of optical properties [57].

It remains to be defined whether the changes in light scatter properties are characteristic of apoptosis or whether they correspond to general features of cell death, whatever the mode of cell death considered. Conversely, OCT measurements as described in this study could be helpful in identifying the scatterers in cells, but other techniques based on elastic light scattering [58-60] or combined with Raman spectroscopy [61] may also be suitable.

\section{Conclusion}

The results from the cultured cells described in this study indicate the ability of OCT to detect and differentiate between viable, apoptotic and necrotic cells, based on their optical properties. This functional supplement to highresolution OCT imaging can be of great clinical benefit, enabling the on-line monitoring of tissues or for feedback in cancer treatment. Furthermore, OCT imaging of apoptosis in the vascular wall might enhance the ability of OCT to detect the vulnerable plaque.

Acknowledgements This work was part of the research programme "Stichting voor Fundamenteel Onderzoek der Materie (FOM)', which is financially supported by the Nederlandse Organisatie voor Wetenschappelijk Onderzoek (NWO), and by the Netherlands Heart Foundation (grant 99.199). Dirk Faber and Maurice Aalders are supported by the Dutch Technology Foundation under grant AGT-7544 (NWO-Veni programme) and grant AGT-7547 (NWOVIDI programme), respectively.

Open Access This article is distributed under the terms of the Creative Commons Attribution Noncommercial License which permits any noncommercial use, distribution, and reproduction in any medium, provided the original author(s) and source are credited.

\section{References}

1. Vermes I, Haanen C (1994) Apoptosis and programmed cell death in health and disease. Adv Clin Chem 31:177-246

2. Kerr JF, Wyllie AH, Currie AR (1972) Apoptosis: a basic biological phenomenon with wide-ranging implications in tissue kinetics. Br J Cancer 26:239-257

3. Thompson CB (1995) Apoptosis in the pathogenesis and treatment of disease. Science 267:1456-1462

4. Vermes I, Haanen C, Reutelingsperger C (2000) Flow cytometry of apoptotic cell death. J Immunol Methods 243:167-190

5. Blankenberg FG, Katsikis PD, Tait JF, Davis RE, Naumovski L, Ohtsuki K, Kopiwoda S, Abrams MJ, Darkes M, Robbins RC, Maecker HT, Strauss HW (1998) In vivo detection and imaging of phosphatidylserine expression during programmed cell death. Proc Natl Acad Sci U S A 95:6349-6354

6. Zhao M, Beauregard DA, Loizou L, Davletov B, Brindle KM (2001) Non-invasive detection of apoptosis using magnetic resonance imaging and a targeted contrast agent. Nat Med 7:1241-1244 
7. Czarnota GJ, Kolios MC, Abraham J, Portnoy M, Ottensmeyer FP, Hunt JW, Sherar MD (1999) Ultrasound imaging of apoptosis: high-resolution non-invasive monitoring of programmed cell death in vitro, in situ and in vivo. Br J Cancer 81:520-527

8. Huang D, Swanson EA, Lin CP, Schuman JS, Stinson WG, Chang W, et al (1991) Optical coherence tomography. Science 254:1178-1181

9. van der Meer FJ, Faber DJ, Perree J, Pasterkamp G, Baraznji Sassoon DM, van Leeuwen TG (2005) Quantitative optical coherence tomography of arterial wall components. Lasers Med Sci 20:45-51

10. Perlman H, Maillard L, Krasinski K, Walsh K (1997) Evidence for the rapid onset of apoptosis in medial smooth muscle cells after balloon injury. Circulation 95:981-987

11. Beuthan J, Minet O, Helfmann J, Herrig M, Muller G (1996) The spatial variation of the refractive index in biological cells. Phys Med Biol 41:369-382

12. Kravtsov VD, Fabian I (1996) Automated monitoring of apoptosis in suspension cell cultures. Lab Invest 74:557-570

13. Mourant JR, Canpolat M, Brocker C, Esponda-Ramos O, Johnson TM, Matanock A, Stetter K, Freyer JP (2000) Light scattering from cells: the contribution of the nucleus and the effects of proliferative status. J Biomed Opt 5:131-137

14. Shiffer Z, Zurgil N, Shafran Y, Deutsch M (2001) Analysis of laser scattering pattern as an early measure of apoptosis. Biochem Biophys Res Commun 289:1320-1327

15. Beauvoit B, Evans SM, Jenkins TW, Miller EE, Chance B (1995) Correlation between the light scattering and the mitochondrial content of normal tissues and transplantable rodent tumors. Anal Biochem 226:167-174

16. Prado A, Puyo C, Arlucea J, Goni FM, Arechaga J (1996) The turbidity of cell nuclei in suspension: a complex case of light scattering. J Colloid Interface Sci 177:9-13

17. Rollins AM, Kulkarni MD, Yazdanfar S, Ung-arunyawee R, Izatt JA (1998) In vivo video rate optical coherence tomography. Opt Express 3:219-229

18. van der Meer FJ, Faber DJ, Baraznji Sassoon DM, Aalders MC, Pasterkamp G, van Leeuwen TG (2005) Localized measurement of optical attenuation coefficients of atherosclerotic plaque constituents by quantitative optical coherence tomography. IEEE Trans Med Imaging 24:1369

19. Izatt JA, Hee MR, Owen GM, Swanson EA, Fujimoto JG (1994) Optical coherence microscopy in scattering media. Opt Lett 19:590-592

20. Faber DJ, van der Meer FJ, Aalders MCG, van Leeuwen TG (2004) Quantitative measurement of attenuation coefficients of weakly scattering media using optical coherence tomography. Opt Express 12:4353-4365

21. van Leeuwen TG, Faber DJ, Aalders MC, Aalders MC (2003) Measurement of the axial point spread function in scattering media using single-mode fiber-based optical coherence tomography. IEEE J Sel Top Quantum Electron 9:227-233

22. Abidor IG, Li LH, Hui SW (1994) Studies of cell pellets: I. Electrical properties and porosity. Biophys J 67:418-426

23. Watanabe T, Voyvodic JT, Chan-Ling T, Sagara H, Hirosawa K, Mio Y, Matsushima S, Uchimura H, Nakahara K, Raff MC (1997) Differentiation and morphogenesis in pellet cultures of developing rat retinal cells. J Comp Neurol 377:341-350

24. Yung LJ, Hall R, Pelinkovic D, Cassinelli E, Usas A, Gilbertson L, Huard J, Kang J (2001) New use of a three-dimensional pellet culture system for human intervertebral disc cells: initial characterization and potential use for tissue engineering. Spine 26:2316-2322

25. Grant S (1998) Ara-C: cellular and molecular pharmacology. Adv Cancer Res 72:197-233

26. Iacobini M, Menichelli A, Palumbo G, Multari G, Werner B, Del Principe D (2001) Involvement of oxygen radicals in cytarabine- induced apoptosis in human polymorphonuclear cells. Biochem Pharmacol 61:1033-1040

27. Kanno S, Higurashi A, Watanabe Y, Shouji A, Asou K, Ishikawa M (2004) Susceptibility to cytosine arabinoside (Ara-C)-induced cytotoxicity in human leukemia cell lines. Toxicol Lett 152:149-158

28. Dessi F, Pollard H, Moreau J, Ben Ari Y, Charriaut-Marlangue C (1995) Cytosine arabinoside induces apoptosis in cerebellar neurons in culture. J Neurochem 64:1980-1987

29. Manakova S, Puttonen KA, Raasmaja A, Mannisto PT (2003) Ara-C induces apoptosis in monkey fibroblast cells. Toxicol In Vitro 17:367-373

30. Vermes I, Haanen C, Steffens-Nakken H, Reutellingsperger C (1995) A novel assay for apoptosis flow cytometric detection of phosphatidylserine expression on early apoptotic cells using fluorescein labelled annexin V. J Immunol Methods 184:39-51

31. Bouffard DY, Momparler RL (1995) Comparison of the induction of apoptosis in human leukemic cell lines by $2^{\prime}, 2^{\prime}$ difluorodeoxycytidine (gemcitabine) and cytosine arabinoside. Leuk Res 19:849-856

32. Guchelaar HJ, Vermes I, Koopmans RP, Reutelingsperger CP, Haanen C (1998) Apoptosis- and necrosis-inducing potential of cladribine, cytarabine, cisplatin, and 5-fluorouracil in vitro: a quantitative pharmacodynamic model. Cancer Chemother Pharmacol 42:77-83

33. Stolzenberg I, Wulf S, Mannherz HG, Paddenberg R (2000) Different sublines of jurkat cells respond with varying susceptibility of internucleosomal DNA degradation to different mediators of apoptosis. Cell Tissue Res 301:273-282

34. Granville DJ, Hunt DWC (2000) Porphyrin-mediated photosensitization: taking apoptosis the fast lane. Curr Opin Drug Discov Devel 3:232-243

35. Barer R, Ross KFA (1953) Refractometry of living cells. Nature 171:720-724

36. Mourant JR, Freyer JP, Hielscher AH, Eick AA, Shen D, Johnson TM (1998) Mechanisms of light scattering from biological cells relevant to noninvasive optical-tissue diagnostics. Appl Opt $37: 3586-3593$

37. van de Hulst, H. C. (1981) Light scattering by small particles. Structure of matter series, Dover, New York

38. Valenzeno DP, Trank JW (1985) Measurement of cell lysis by light scattering. Photochem Photobiol 42:335-339

39. Wilson JD, Bigelow CE, Calkins DJ, Foster TH (2005) Light scattering from intact cells reports oxidative-stress-induced mitochondrial swelling. Biophys J 88:2929-2938

40. Wilson JD, Giesselman BR, Mitra S, Foster TH (2007) Lysosomedamage-induced scattering changes coincide with release of cytochrome C. Opt Lett 32:2517-1519

41. Narita M, Shimizu S, Ito T, Chittenden T, Lutz RJ, Matsuda H, Tsujimoto Y (1998) Bax interacts with the permeability transition pore to induce permeability transition and cytochrome c release in isolated mitochondria. Proc Natl Acad Sci U S A 95:14681-14686

42. Finucane DM, Bossy-Wetzel E, Waterhouse NJ, Cotter TG (1999) Bax-induced caspase activation and apoptosis via cytochrome $\mathrm{c}$ release from mitochondria is inhibitable by Bcl-xL. J Biol Chem 274:2225-2233

43. Kroemer G, Galluzzi L, Brenner C (2007) Mitochondrial membrane permeabilization in cell death. Physiol Rev 87:99-163

44. Boustany NN, Tsai Y-C, Pfister B, Joiner WM, Oyler GA, Thakor NV (2004) BCL-xL-dependent light scattering by apoptotic cells. Biophys J 87:4163-4171

45. Darzynkiewicz Z, Bedner E, Smolewski P (2001) Flow cytometry in analysis of cell cycle and apoptosis. Semin Hematol 38:179-193

46. Bonfoco E, Ceccatelli S, Manzo L, Nicotera P (1995) Colchicine induces apoptosis in cerebellar granule cells. Exp Cell Res 218:189-200 
47. Cervinka M, Cerman J, Rudolf E (2004) Apoptosis in Hep2 cells treated with etoposide and colchicine. Cancer Detect Prev 28:214226

48. Bauriedel G, Hutter R, Welsch U, Bach R, Sievert H, Luderitz B (1999) Role of smooth muscle cell death in advanced coronary primary lesions: implications for plaque instability. Cardiovasc Res 41:480-488

49. Dhume AS, Soundararajan K, Hunter WJ III, Agrawal DK (2003) Comparison of vascular smooth muscle cell apoptosis and fibrous cap morphology in symptomatic and asymptomatic carotid artery disease. Ann Vasc Surg 17:1-8

50. Kolodgie FD, Narula J, Burke AP, Haider N, Farb A, Hui-Liang Y, Smialek J, Virmani R (2000) Localization of apoptotic macrophages at the site of plaque rupture in sudden coronary death. Am J Pathol 157:1259-1268

51. Durand E, Scoazec A, Lafont A, Boddaert J, Al Hajzen A, Addad F, et al (2004) In vivo induction of endothelial apoptosis leads to vessel thrombosis and endothelial denudation: a clue to the understanding of the mechanisms of thrombotic plaque erosion. Circulation 109:25032506

52. von der Thusen JH, van Vlijmen BJ, Hoeben RC, Kockx MM, Havekes LM, van Berkel TJ, et al. (2002) Induction of atherosclerotic plaque rupture in apolipoprotein E-/- mice after adenovirus-mediated transfer of P53. Circulation 105:2064-2070

53. Bedner E, Li X, Gorczyca W, Melamed MR, Darzynkiewicz Z (1999) Analysis of apoptosis by laser scanning cytometry. Cytometry 35:181-195
54. Chalut KJ, Ostrander JH, Giacomelli MG, Wax A (2009) Light scattering measurements of subcellular structure provide noninvasive early detection of chemotherapy-induced apoptosis. Cancer Res 69:1199-1204

55. Mulvey CS, Curtis AL, Singh SK, Bigio IJ (2007) Elastic scattering spectroscopy as a diagnostic tool for apoptosis in cell cultures. IEEE J Sel Top Quantum Electron 13:1663-1670

56. van Manen HJ, Verkuijlen P, Wittendorp P, Subramaniam V, van den Berg TK, Roos D, et al (2008) Refractive index sensing of green fluorescent proteins in living cells using fluorescence lifetime imaging microscopy. Biophys J 94:L67-L69

57. Faber DJ, van Leeuwen TG (2009) Are quantitative attenuation measurements of blood by optical coherence tomography feasible? Opt Lett 34:1435-1437

58. Amelink A, Sterenborg HJCM (2004) Measurement of the local optical properties of turbid media by differential path-length spectroscopy. Appl Opt 43:3048-3054

59. Amelink A, Sterenborg HJCM, Bard MPL, Burgers SA (2004) In vivo measurement of the local optical properties of tissue by use of differential path-length spectroscopy. Opt Lett 29:1087-1089

60. Reif R, A'Amar O, Bigio IJ (2007) Analytical model of light reflectance for extraction of the optical properties in small volumes of turbid media. Appl Opt 46:7317-7328

61. Patil CA, Bosschaart N, Keller MD, van Leeuwen TG, Mahadevan-Jansen A (2008) Combined Raman spectroscopy and optical coherence tomography device for tissue characterization. Opt Lett 33:1135-1137 